\title{
Study on Design Method of Chinese Han Embroidery in Silk Modern Women Clothing
}

\author{
Yuanmei Zhang \\ The Garment College of Wuhan Textile University \\ Wuhan, Hubei, China
}

\begin{abstract}
This paper takes the protection and application of the world national culture in silk women clothing as research point. Especially the protection and application of the intangible cultural heritage inheritance and innovation. It focuses on the application of Han embroidery in silk women clothing designing. First, the paper analyzes method of style design and selection of materials about silk women clothing. Through the study about Han embroidery in silk women clothing design, it expresses the necessity about protection of national culture and the traditional skills and innovative. At the same time, we can also through the research to improve the performance of the Han embroidery on the silk clothing.
\end{abstract}

Keywords-silk women clothing; Han embroidery; intangible cultural heritage; inheritance and innovation; design method

\section{INTRODUCTION}

China is not only a silk vast country, but also is an ancient country with silk. It has a legend about origin of silk. It has the ancient emperor's wife, she teach people to rear silkworm and weave silk fabric for making clothes.The earliest Chinese nation spreads the silk culture and silk craft to the world. In tang and song dynasties, the silk production and technology both reached the peak. Now China's silk products have been sold at home and abroad, silk technology level also has great development and progress, but in some of the famous silk costume brand in the world is few.

\section{The Close Relations BETWEEN EMBROIDERY AND SILK WOMEN CLOTHING}

The silk material is always the Optimum seeking carrier of the embroidery expression,. through the ages, many excellent embroidery clothing and art works all used silk materials to express design inspiration. Today there are many famous designers and embroidery artists to create many excellent embroidery works, design one handed down from ancient times, such as Ne. tiger brand and Guo Pei , etc. But most works still stay in the texture closely, cloth stiff sense, the embroidery in the thin soft silk material also has many problems. The main problem is that the soft, thin silk material usually has the problem of disconnection and laddering in the process of embroidery. If the embroidery pattern is more complex, colors or pin number, the appearance of silk women clothing is not calm and smooth, easy to form wrinkle, affecting the appearance of silk clothing and

The Project Supported by Humanities and social science project of Hubei Provincial Education Department (project number:17Q092). wearing comfort.

The existing problems of Embroidery about the silk women clothing is not only embroidery craft, but also embroidery design in silk women clothing. We can use some of the methods to avoid and improve design .Following we analyze design methods to explore Chinese Han embroidery in Hubei province about the silk clothing design

\section{THE HAN EMBROIDERY AND SILK WOMEN ClOTHING DESIGN}

Chinese traditional embroidery is an important part of the Chinese excellent national culture. Embroidery gets the attention of the world because of its elegant appearance, exquisite technology and gorgeous color. Embroidery is widely applied to clothing, household and decorations, especially the women's clothing. It can increase the women's clothing more aesthetic value and artistic charm. In China there are four famous embroidery, $\mathrm{Su}$ embroidery, Shu embroidery, Xiang embroidery and Yue embroidery. But in China there are many other good unique embroidery, for example Han embroidery in Hubei province. The protection and inheritance of the Han embroidery is relatively mature and perfect, but the skill of innovative applications is the main problem. Below is for the design and Han embroidered silk women design application as the view point, to discuss the relationship between silk women clothing design method and Han embroidery.

\section{Design Method about Han EMbroidery IN SILK WOMEN CLOTHING}

The traditional Han embroidery pattern takes from animals and plants in nature, mountains and rivers natural landscape, to bring people comfort and peace of mind. These patterns are very suitable for modern people's aesthetic in society. Using Han embroidery patterns in silk women clothing, considering the cost and embroidery clothing effect, we can take clever design to avoid or solve problems about the silk clothing embroidery.

First, try to avoid the using of Han embroidery pattern in large area. The large embroidery pattern layout can affect the garment effect of silk dress finally. Especially in soft, thin silk material with the large area of embroidery craft, it will make the clothing become hard, change the silk simple sense of smooth. In addition, a large area of embroidery can make silk material wrinkle, affect the smooth texture of the 
material. So for the Han embroidery pattern design in the soft and smooth silk fabric, we must to avoid too large areas of the Han embroidery pattern design. In the design stage we should use ingenious method to avoid problems with garment wrinkle starched and Keep silk clothes perfect appearance.

Second, we also use Han embroidery pattern design in targeted positions of silk women clothing. It can play adornment effect for clothing, also can reduce the influence of silk material texture and appearance. Such as clothing collar and cuffs, placket, chest and waist for Han embroidery pattern design, etc. Above clothing parts with Han embroidery are important parts for human body and clothing. These are the human body structure parts of the human body curve parts. These parts have very good supporting effect for clothing. In these parts for the Han embroidery pattern layout can ensure that silk clothing style characteristic, also can avoid avoid garment wrinkle starched problems.

In addition to the special parts using Han embroidery pattern design, it can also choose different silk fabrics to rich the effect of clothing. We can design more styles with the rich mufti-pieces design, different texture of silk material to selectively reasonable fabric collocation. On the choice of material, we can choose the hard texture of silk damask and brocade be the material of the Han embroidery, and choose the thin soft silk to shape elegant gently silk style. The stiff and soft silk material collocation, it not only solve the problems about the embroidery on the thin silk material, but also can rich style feeling of the silk clothing and appearance.

Finally, we can take specific Han embroidery pattern design, and improve the tools of embroidery and craft technique in the process of the Han embroidery to avoid embroidery problems. Such as the choice of embroidery thread, embroidery needle and craft and so on. Above improving for the embroidery craft and material improvement innovation can improve the expression and effect of the Han embroidery in silk women clothing.

\section{CONCLUSION}

Traditional national art and technique is precious material wealth and the spiritual and cultural heritage in every country. Chinese Han embroidery application on silk women clothing is reuse and innovation of national embroidery culture. This application is a kind of special protection. We call it 'protection of the living condition method'. To traditional culture and art we not only focus on the history, but also analyze the traditional with modern fashion in order to keep pace with the times.

\section{REFERENCES}

[1] Zhang yuanmei. 'Fashion design ', fashion guide, Wuhan textile university, Wuhan, 2015(3): cover work.

[2] Zhang yuanmei. 'Han embroidery clothing design', hundred schools in arts, magazine of hundred schools in arts. Nanjing, 2015(1):285.

[3] Http://www.china-4.com/news/shownews.asp?id=7284.Silk Net. A brief history of the silk development in China[EB/OL]. (2011-05-17) [2013-03-06]. 